\title{
足関節骨折の治療と予後
}

$\begin{array}{rlllll}\text { 三菱病院整形外科 } & & & & \\ \text { 岩 永 博 隆・瀬 良 敬 祐 } \\ \text { 竹 下 } & \text { 豊 秋・梅 木 } & \text { 義 } & \text { 臣 } \\ \text { 濱 里 } & \text { 雄次郎 } & & & \\ \text { 長崎大学整形外科 } & & & & & \\ \text { 乗 松 敏 晴 } & & & \end{array}$

\section{Follow-up Study of the Treatment of Ankle Fractures}

by

\author{
Hirotaka Iwanaga, Keisuke Sera, Toyoaki Takeshita, \\ Yoshiomi Umeki and Yuujirou Hamasato \\ Department of Orthopedic Surgery, \\ Nagasaki Mitsubishi Hospital \\ Toshiharu Norimatsu \\ Department of Orthopedic Surgery, \\ Nagasaki University School of Medicine
}

This paper presents an analysis of the results of the treatment of ankle fractures. A follow-up study was performed on 78 of 112 cases of ankle fractures treated surgically between 1977 and 1988. The fractures were grouped into five types according to the classification of Lauge-Hansen. The subjective clinical results were good in 70 , fair in 5 and poor in 3. The objective results were good in 61 , fair in 13 and poor in 4 according to Gregory's evaluation. Anatomical reduction and rigid fixation significantly affected the clinical results.

\section{はじめに}

足関節骨折は日常よく遭遇する骨折の一つで，日常 生活における一般外傷，スポーツ外傷，交通事故，労 働災害などの原因で引き起こされる。

我々はその治療として, 原則的に rigid internal fixation と early joint movement を行ってきた。1977 年 5 月より1988年12月までの過去11年間に当院で行っ た手術症例は112例であった。今回，そのうちの78例 について予後調查が行えたので報告する.

\section{対象および方法}

手術症例数は男性72例，女性40例で，そのうち実際 に検診を行いえた男性46例，女性32例の78症例を対象
とした．受傷時年令は14才から75才で，平均37才であ った。

骨折の分類には Lauge-Hansen ${ }^{1), 3 \mid}$ の分類を使用し た。また，予後調査の結果を Gregory ${ }^{2}$ ) の評価法（表

1) に基づき, subjective result と objective result に分け，共に score $4 \sim 3$ を good，2 fair，1 0 を poor として評価した.

\section{結果}

受傷原因別症例数と骨折型別症例数を表 2 に示す. 受傷原因別にみると，スポーツ外傷と一般外傷では SL 型が多く，労動災害では PL 型が，交通事故では SL 型, S 型が多くを占めた. Lauge-Hansen の分類で は分類不可能な Unknown 型は60\%が労働災害による 
表 1 Gregory の評価法

Scoring of Subjective Clinical Evaluation

\begin{tabular}{l}
\hline Score \\
\hline 4 No pain; normal ankle \\
3 Pain is noted only after severe and prolonged stress; participation in sports and \\
ability to walk or work not limited \\
2 Pain is moderately incapacitating, but no cane or other walking aid is used; mild \\
analgesics are occasionally required; walking is restricted, but patient is able to \\
walk more than five blocks; patient may have changed occupations due to painful \\
ankle but works full-time and has had no reduction in pay \\
1 Pain is severe and may require use of a brace or cane and daily analgesics; walk- \\
ing is restricted to less than five blocks; patient is unemployable on a full-time \\
basis due to the ankle but is able to care for himself \\
Pain is constant and incapacitating; patient is unable to walk sufficiently to care \\
for himself and desires fusion of the ankle
\end{tabular}

Scoring of Objective Clinical Evaluation

\begin{tabular}{l}
\hline Score \\
\hline 4 Normal \\
3 Active and passive dorsiflexion, plantar flexion, pronation, and supination are pain- \\
less, and range is more than two-thirds that of the uninjured ankle; no tenderness \\
2 All movements of the ankle are painless and range is one-third to two-thirds \\
that of the normal ankle; slight tenderness about the ankle joint \\
1 All movements of the ankle are painless and range is less than one-third that of \\
normal; definite limp \\
0 Ankle stiff and painful; severe antalgic gait; varus or valgus deformity of the \\
ankle; any ankle that was fused was also placed in this category
\end{tabular}

表 2 受傷原因

\begin{tabular}{|c|r|r|r|r|c|}
\hline 骨折型 & スポーツ & 労 災 & 交通事故 & その他 & 計 \\
\hline $\mathrm{S}$ & $1(1)$ & $1(1)$ & $7(4)$ & $5(0)$ & $14(6)$ \\
\hline $\mathrm{SL}$ & $15(10)$ & $5(5)$ & $8(5)$ & $24(18)$ & $52(38)$ \\
\hline $\mathrm{P}$ & $0(0)$ & $5(4)$ & $3(2)$ & $0(0)$ & $8(6)$ \\
\hline $\mathrm{PL}$ & $7(7)$ & $9(4)$ & $5(4)$ & $7(6)$ & $28(21)$ \\
\hline Unknown & $1(1)$ & $6(5)$ & $1(1)$ & $2(0)$ & $10(7)$ \\
\hline 計 & $24(19)$ & $26(19)$ & $24(16)$ & $38(24)$ & $112(78)$ \\
\hline
\end{tabular}

\section{ものであった。}

一方，骨折型別にみると，SL 型，PL 型の順に多

く, 両者で全体の約70\%を占めていた.

Gregory の評価法に基づく結果を表 3 に示す. 型別 に scoreをみると, subjective result ではS 型, P 型, Unknown 型は全例 good であった。一方, SL 型は good 34例, fair 3例, poor 1 例, PL 型は good 17例, fair 2例, poor 2例であった. objective result につ いては, $\mathrm{S}$ 型のみ全例 good で, 他の SL, P, PL,
Unknown 型は subjective result に比べ, fair または poor の症例が増加していた.

全症例に関して subjective result では約90\%が, objective result では約78\%が good であった.

次に足関節可動域についてみると, 背屈はいずれの 型も $10^{\circ}$ 以上であった (表 4 )。一方, 底屈は平均 $32.2^{\circ}$ の Unknown 型を除くと, すべてが $35^{\circ}$ 以上であった. 代表的症例を供覧する.

症例 1.16才, 男性, PL 型 (図 1). 
表 3 結 果

Subjective Results

\begin{tabular}{|c|c|c|c|}
\hline $\begin{array}{c}\text { Type of } \\
\text { fracture }\end{array}$ & $\begin{array}{c}\text { Good } \\
\text { (score 3 4) }\end{array}$ & $\begin{array}{c}\text { Fair } \\
\text { (score 2) }\end{array}$ & $\begin{array}{c}\text { Poor } \\
\text { (score 0 1) }\end{array}$ \\
\hline S & 6 & 0 & 0 \\
\hline SL & 34 & 3 & 1 \\
\hline P & 6 & 0 & 0 \\
\hline PL & 17 & 2 & 2 \\
\hline Unknown & 7 & 0 & 0 \\
\hline 計 & 70 & 5 & 3 \\
\hline
\end{tabular}

Objective Results

\begin{tabular}{|c|c|c|c|}
\hline $\begin{array}{c}\text { Type of } \\
\text { fracture }\end{array}$ & $\begin{array}{c}\text { Good } \\
(\text { score 3 4) }\end{array}$ & $\begin{array}{c}\text { Fair } \\
(\text { score 2) }\end{array}$ & $\begin{array}{c}\text { Poor } \\
(\text { score 0 1) }\end{array}$ \\
\hline S & 6 & 0 & 0 \\
\hline SL & 30 & 6 & 2 \\
\hline P & 5 & 1 & 0 \\
\hline PL & 15 & 4 & 2 \\
\hline Unknown & 5 & 2 & 0 \\
\hline 計 & 61 & 13 & 4 \\
\hline
\end{tabular}

表 4 足関節可動域

\begin{tabular}{|c|c|c|c|}
\hline 骨折型 & 症例数 & 背屈 $\left(^{\circ}\right)$ & 底屈 $\left({ }^{\circ}\right)$ \\
\hline $\mathrm{S}$ & 6 & $11.0 \pm 3.1$ & $35.8 \pm 2.9$ \\
\hline $\mathrm{SL}$ & 38 & $12.6 \pm 6.3$ & $39.8 \pm 8.1$ \\
\hline $\mathrm{P}$ & 6 & $13.9 \pm 2.1$ & $37.2 \pm 7.7$ \\
\hline $\mathrm{PL}$ & 21 & $14.6 \pm 4.1$ & $42.1 \pm 4.8$ \\
\hline Unknown & 7 & $10.7 \pm 3.3$ & $32.2 \pm 4.1$ \\
\hline \multicolumn{2}{|c|}{ 平 均 值 } & $12.6 \pm 6.3$ & $39.3 \pm 8.3$ \\
\hline
\end{tabular}

跳び箱の着地で受傷. 骨接合術を行い, 評価は good である。

症例 2.39才，男性，Unknown 型（図 2).

ソフトボール中のスライディングで受傷. 2 週間の 直達牽引後, 骨接合術と三角勒帯縫合を行った。評 価は現在, subjective には, good, objective には fair であるが, 関節軟骨自体の障害により将来 OA に移行すると思われる症例である.

症例 3. 37才, 男性, PL 型 (図 3).

転倒にて受傷. 術後 3 週目に転院. 1 年後の現在も

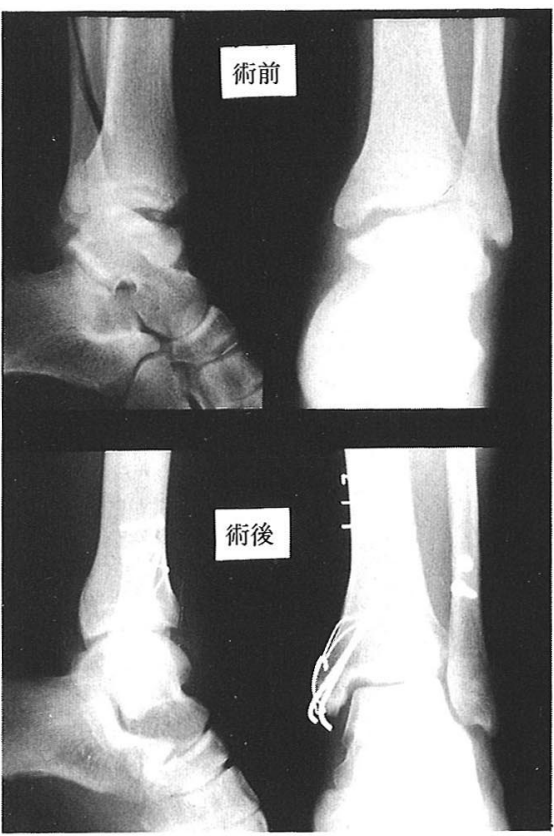

図116才男性 PL 型

現在スポーツ復帰ができ, 評価は good である.

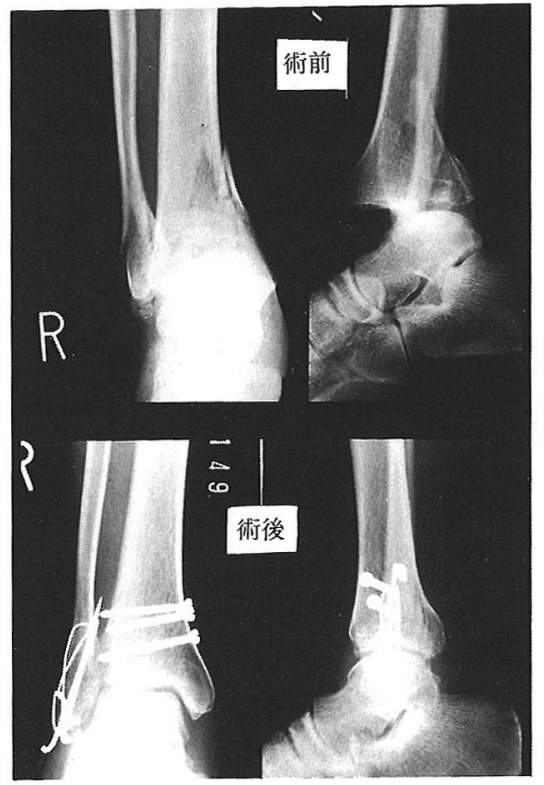

図 2 39才男性 Unknown 型

現在仕事上ほとんど支障がない状 態であるが，関節軟骨自体の障害に より, 将来変形性関節症に移行する と思われる. 


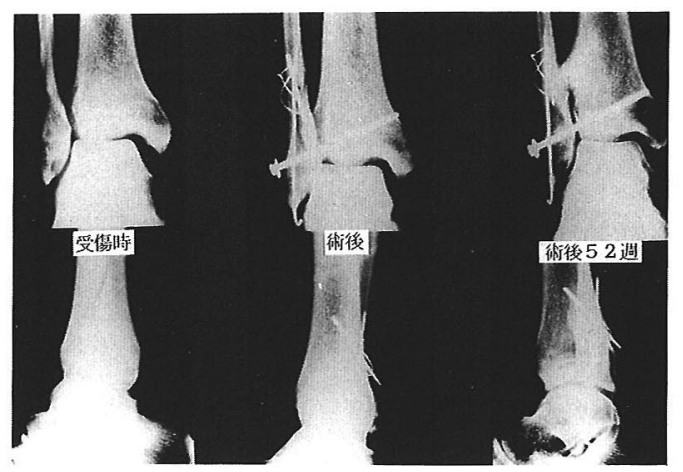

図 337 男性 PL 型 現在も怪腓間は固定された状態で, 怪腓勒帯結合部に骨化を認め, 評価 は poor である.

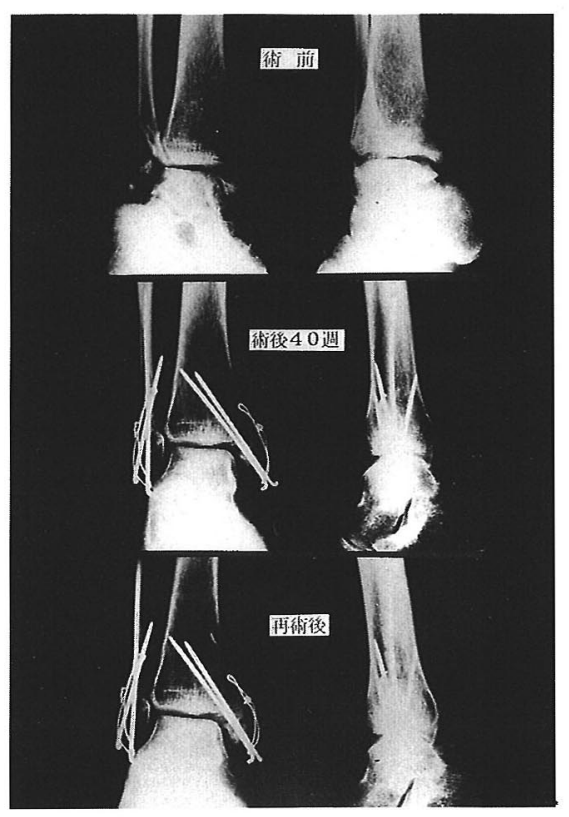

図438才 女性 SL 型

受傷後 6 力月間, 内果が脱臼位の まま放置されていたため, 偽関節と なり，骨移植を追加した。評価は poor である.

怪腓間固定はそのままで, 怪腓勒帯結合部に骨化を 認め, 評価は poor である. 症例 4.38才, 女性, SL 型 (図 4).

転倒にて受傷. 他院にて 6 力月間, 保存的に治療さ
れた後, 当院で骨接合術と骨移植を行うも偽関節と なり，骨移植を追加した症例である，評価は poor である。

$$
\text { 考 . 察 }
$$

足関節骨折の分類には，その発生機転に基づき，骨 折のみでなく勒帯損傷をも含めた Lauge-Hansenの分 類を用いた. 結果は諸家の報告よりも PL 型が $25 \%$ と 多かった.

受傷原因と骨折型の関係をみると，一般に言われて いるようにスポーツでは SL 型が, 労働災害では PL 型が多かった.

足関節可動域は背屈が平均 $12.6^{\circ}$, 底屈は平均 $39.3^{\circ}$ でほほほ良好な結果を得た。しかし，骨折型別にみる と, Unknown 型では背屈 $10.7^{\circ}$, 底屈 $32.2^{\circ}$ で, 他の 型に比べて関節可動域の制限を認めた。 これは荷重関 節面そのものに骨折がおよび，その多くは粉砕骨折で あるいわゆる compression type を含んでいるためと 考える。

次に Gregory の評価法において subjective result と objective result を比較すると $\mathrm{S}$ 型, $\mathrm{P}$ 型では両者 はほぼ一致していたが, SL 型, PL 型, Unknown 型 では objective result の方がscore は低かった.これ は疼痛や在痛ではなく, 関節可動域制限によるものと思 われた，全症例について good の占める割合は subjective result で約90\%, objective result で約78\% と良好な成績を得た. 次に poor の 4 症例について検 討を加える. SL 型の 2 例は内果が転位したままで 6 力 月間も放置されていた例（症例 4) と他医にて不必要 な怪腓間固定を受け，骨化をきたした例であった。 PL 型の 2 例は長期にわたる脛腓間固定により骨化を 生じた例（症例 3 ）と片麻疩の䍦患側に骨折を生じた 例であった。

一般に予後は SL 型では良く, Unknown 型では悪い と言われているが, 今回の調查ではSL 型は good 30例, fair 6例, poor 2 例と比較的悪く, Unknown 型 は good 5 例, fair 2例と良かった.これは関節面の $25 \%$ 越える症例, 即ち, Maale ${ }^{4)}$ らの分類による Type 2A, 2B が SL 型, PL 型に含まれていたためと 考えられた。

最後に, 今回の調查を通して本骨折においては解剖 学的再建, 確実な内固定, 早期の関節可動域改善訓練が 
きわめて重要であると思われた.

\section{ま と め}

1. 当院における過去11年間の足関節骨折の手術症例 112例のうち，78症例の予後調査を行った.

2.Gregory の評価法によると subjective result と objective result では，それぞれ全症例の約90\%， 約78\%が good であった.

3.いずれの型も, 正確な解剖学的整復と確実な固定 が行われた症例は良好な結果を得ていた。

4. SL 型, PL 型の一部では, 怪腓靱帯部の骨化や 偽関節をきたした症例を認めた。

\section{参 考 文 献}

1) Burwell, H. N., Charnley, A.D.: The treatment of displaced fractures at the ankle by rigid internal fixation and early joint movement. J. Bone Joint Surg., 47-B : 634-660, 1965.

2) Gregory, J. et al.: Precise evaluation of the reduction of severe ankle fractures. J. Bone Joint Surg., 56-A : 979-993, 1974.

3) Lauge-Hansen, N.: Fractures of the ankle III. Am. J. Roentogenol., 71: 456-471, 1954.

4) Maale, G.: Fractures through the distal weightbearing surface of the tibia. Orthopedics, 3:517521, 1980.

5）真島 隆三ほか：足関節骨折の治療と予後. 骨折, 9:195-198, 1987.

6）乗松 敏晴ほか: 足関節果部骨折の長期治療成績. 整形・災害外科, $26: 635-642,1983$.

7）乗松 敏晴: Plafond 骨折. 骨折・外傷シリーズ, $9: 1-15,1988$. 